\title{
Electronic Taxation and Tax Fraud in Rivers State
}

\author{
Ifeanyi Madumere $\mathbf{P h D}^{* 1}$, George IheanachoUbani ${ }^{2}$ \\ ${ }^{1}$ Department of Accounting, Faculty of Management Sciences Federal University, Otuoke, Bayelsa State, \\ Nigeria \\ ${ }^{2}$ Department of Accounting, Faculty of Business Studies, Ignatius Ajuru University of Education, Rumuolumeni, \\ Port Harcourt, Nigeria
}

*Corresponding Author: Ifeanyi Madumere PhD, Department of Accounting, Faculty of Management Sciences Federal University, Otuoke, Bayelsa State, Nigeria

\begin{abstract}
Every nation is expected to take care of her citizens by providing social amenities. While the citizens must support the state by paying their tax. This study focused on electronic taxation and tax fraud in Rivers State of Nigeria. To carry out this study, literature was reviewed, five hypotheses proposed and analysed using simple and Pearson product correlation coefficient which is used to ascertain the relationship of the variables. Taro Yamene sampling techniques was used to determine the sample size from a population of 572 to a sample of 236 from the 15 tax offices in Rivers State. The findings revealed that: electronic tax filing system has a transposed relationship with tax evasion, that electronic tax payment system has a reverse relationship with tax evasion. The studya relationship exist between electronic tax filing system as well as electronic tax payment system. Technology also was observed to have encouraged tax elusion while reducing tax under-invoicing. Based on the preceding, we recommends among others that: all institutions saddled with tax matters should hold firm to electronic taxation as this will help to reduce tax evasion and tax underinvoicing. Tax personnel should be sufficient and qualified to keep up-to-date with modern developments in the tax world. There is also a need for acceptable tax equipment and facilities to ensure the quickly evolving electronic tax system. This will not only reduce occurrences of tax avoidance and tax under-invoicing but also will make a tax payment system easy, transparent and simple.
\end{abstract}

Keywords: Electronic Tax System, Electronic Tax Filing System, Electronic Tax Payment System, Tax Evasion, Under Invoicing, Technology.

JEL classification: $H 71$, I 138, M41.

\section{INTRODUCTION}

Government all over the world needs money to meet-up with responsibility owed to the citizen. It is the duty of government to provide good schools, hospitals pipe borne water, good roads etc. this can only be achieved if proper machinery is put in place to monitor sources of government revenue. Everyday people are being disturbed in their offices and in their business places by people to collect tax in for government. These are supposedly committee members set up by government. Data from the Central Bank of Nigeria (2000), revealed that, oil and gas exports accounted for more than 98 per cent of export earnings and about 83 per cent of federal government revenue, as well as producing more than 40 per cent of its GDP. It also bargains 95 per cent foreign exchange earnings. Therefore, a very profitable means of generating the amount of revenue needed for providing the necessary substructure for a country a well-structured tax system.

Taxation is basically the process of collecting taxes within a particular location. In this regard, tax has been defined as "a monetary charge imposed by the Government on persons, entities, transactions or properties to yield revenue". It has also been defined as 'the enforced proportional contributions from persons and property, levied by the State by virtue of its sovereignty for the support of Government and for all public needs". Taxes may also be defined as a "pecuniary burden laid upon individuals or property to support government expenditure (Kiabel\&Nwikpasi 2009). A tax "is not a voluntary payment or donation, but an enforced/compulsory contribution, exacted pursuant to legislative authority" and is "any contribution imposed by government", whether under the name of duty, custom excise, levy or other name. Taxes are therefore defined as a financial charge or levy imposed upon an 
individual or legal entity by a State or a component of the State. A tax is usually a monetary charge on a person's or entity's income, property or transaction and is usually collected by a defined authority at the Federal and State Level. Taxes may be direct or indirect and may be imposed on individual basis, on entities, on assets and on transactional basis.

Over time, the Nigerian tax system has not been able to influence these perceived objectives as a result of some delays and challenges which include; lack of stewardship amongst taxpayers, collection of taxes, complex tax payment method and tax offsetting; lack of technical experience, tax evasion, fraud, government instability which prompts noncompliance with relevant tax laws, poor database recordkeeping etc. Technology is meant to help us improve our daily activities for the best with less task. Its impact can be felt in every aspect of our lives such as education, performance, communication, commerce; handling of government including taxation. Information Technology (IT) is a very vital element of tax administration improvement as it enables tax administrators to gather and analyse information, to proactively achieve workload, meet set goals, foster a co-operative engagement with taxpayers and to regulate the treatment of taxpayers and thus help the uniform application of the law, thus according to Lee (2016) mandatory electronic tax invoicing has been credited with lowering tax compliance costs and raising the transparency of business transactions.

E-taxation can be described as government revenue collection made-easyas it has turned to be a master tool in contesting the challenges of any tax system as it provides information, education and support to taxpayers and enables compliance and management. It is the computerisation of core duty processes. E-tax systems are often thought of completely as IT support to taxpayer services sinceit also provide information, education, and help taxpayers due to its unique types of machinery such as electronic registration and filling, automatic updates of taxpayer information etc. It also guarantees the compact cost of administering taxes. According to the World Bank and PwC Paying Taxes Report (2015), sixty-six economies had fully applied electronic filing and payment of taxes as of 2010. Also, twenty of them adopted the system in the former seven years.

The Federal Inland Revenue board and the state board of internal revenue as well as local government revenue committees are saddled with the responsibility of administering taxes at the federal, state and local levels individually. The Nigerian government through these public boards has made determinations to restructure the tax system in a well-structured and coordinated manner. One of these is the application of an electronic tax system called the integrated tax administration system 'which if applied properly would enhance compliance and reduce the problem of tax information and statistics. When this is achieved, government revenue generation through tax would be boasted as well as help in stabilizing the Nigerian economy. The Electronic-tax system according to Armstrong, Blouin\&Larcker (2012)has a-hand full of benefits which include: promotion of efficiency, accountability, compliance and also; lessening the workload of the taxpayers and dropping operational cost and curb leakages in the Nigerian tax system.

Tax as a major source is a compulsory levy set by government through its various agencies on the income, capital or investing of its subjects (Morozumi\&Veiga 2016). These charges are made on personal income such as salaries, business profits, interests, dividends commissions, royalties or rent, capital gain and petroleum profits. According to Armstrong, Blouin, and Larcker (2012) tax payment is a demonstration of patriotism. It is a civic duty, imposed and influence by the government through legislation on the citizens, subjects and companies to enable her finance public utilities and perform other social responsibilities.

Before now, it has been a common practice to collect tax payment relatively on behalf of one's self and partly for the government. Some individuals including some corporate organisations prefer to bribe tax officials relatively than pay actual taxes. Some tax assessors conspire with taxpayers, particularly concerning the Personal Income Tax (PIT), or in some belongings, in construction with the assessment. Therefore, taxes paid end in private pockets and accounts instead of government coffers. Despite all effort by the government over the years to track down most these problems and crisis fronting the collection of tax in Nigeria, not much has been done to improve revenue-generating by the government. This attitude has eroded tax awareness on the part of Nigeria. Therefore, etaxation is properly applied it may reduce all these problems and improvement government (Madumere, 2019).

More so, the Nigerian tax system which is made up of tax policy, laws and administration have faced so many challenges over the years as stated above which have brought about dis-organisation and 
increased administrative cost. The income generated from tax in any economy is dependent on the tax system put in place. This possibly influenced the decision of the Federal Government of Nigeria (FGN), which is 1991 set up a Study Group on the Review of the Nigerian Tax System and Administration to improve revenue from various tax sources. According to FIRS press release as quoted by Madumere (2019),"approximately 12 billion naira disappears into the pocket of individuals not to reference the problems of difficulty of payment, inaccessibility of tax statistics and information, poor technological exposure on the part of both taxpayers and tax authorities.

The introduction of e-tax system in advanced economies such as United States, United Kingdom, Germany China, Malaysia, Slovenia etc. has helped reduce time to fulfil the 3 main taxes(profit, labour and consumption) as well as provided dependable and accurate tax statistics. The Joint Tax Board, the Federal Inland Revenue Service and some State Internal Revenue Service have or are in the process of applying electronic tax systems. Whilst the introduction of this system (e-taxation) is commendable it is important to note that there are anticipated challenges that would face the adoption of this system that could put a rinsing on the already flawed tax systems. E-tax system if administered properly can be the solution to the unequal tax system in operation in Nigeria. Hence this study aims to evaluate the inherent problems electronic taxation and tax fraud in Nigeria would face.

This paper is organised in five sections. Next to the introduction is section two which discusses the literature review and hypotheses development with emphasis on: conceptual review, theoretical review and review of empirical studies. Section three dwells on the methodology. This is followed by section four which focuses on results and discussion of findings, and section five presents the conclusion and recommendations.

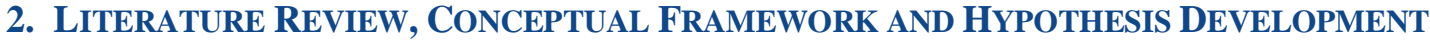

Fairness has long been a major principle of tax reform. In the years since the global financial crisis, concerns about widening income inequality have grown and begun to frame tax policy debates in many jurisdictions, particularly in developing markets, where income inequality increased on average by $11 \%$ between 1990 and 2010, according to the United Nations Development Programme. Designing a "fair" tax system is not an easy process. Chile, a country that has recently undertaken tax reforms, is a perfect example of this.

The intention of tax reduction by organisations is to reduce tax expense is considered as old as the inception of taxation itself as organisations are always trying to exploit loopholes in the complexities of the existing tax system. The main motive for such practices is to reduce expenses, thereby increasing the firm's net profit. Taxation is used as a tool of fiscal policy in controlling a nation's economy (Nwaobia, Kwarbai\& Ogundajo). It is used by government as a means of encouraging the growth of certain sectors and infant industries as well as encouraging investments in an economy. Corporate income tax revenue in Nigeria according to Thomas (2017) is 30\%Companies incorporated in Nigeria are taxed on their profits worldwide, but nonresident firms are only subject to tax on the profits of their Nigerian operations. There is an initial three-yeartax holiday for companies involved in gas utilisation downstream operations, as well as for those using gas for industrial projects. This break can be extended for another two years.

\subsection{Indirect Taxes and Other Taxes}

Nigeria has a 5\% (now 7.5\%) value-added tax (VAT) on certain goods and services, including imported products and professional services. The Nigerian Custom services should account for revenue collected for the government not later than 60 days for all monies collected. All these should help the government to implement their budget. Nigeria applies a 10\% withholding tax on dividends along with recipients in non-treaty countries. However, dividends distributed from the profits of companies with pioneer status along with after-tax profit from petroleum are not subject to the tax.

\subsection{Administration}

Nigeria ranked 179 in the area of paying taxes in the World Bank's doing Business 2015 report. It takes companies 908 hours, on average, each year to prepare, file and pay their taxes in Nigeria. Government needs details of revenue collected to prepare the budget for the preceding year. It is expected that government with good control measures should be able to collect all the taxes not later than 120 days after 31 December in the new financial year. 
Tax administration is the act of putting machinery in place for government to be able to account for the management of tax requirements specified by the tax law in a State. Its primary task is to ensure that the right amount of tax is paid by the right taxpayer at the right time, providing the government with the needed revenue to deliver goods and services, which implies that an administration that achieves this task is effective at the most minimal cost.

\section{Conceptual Framework}

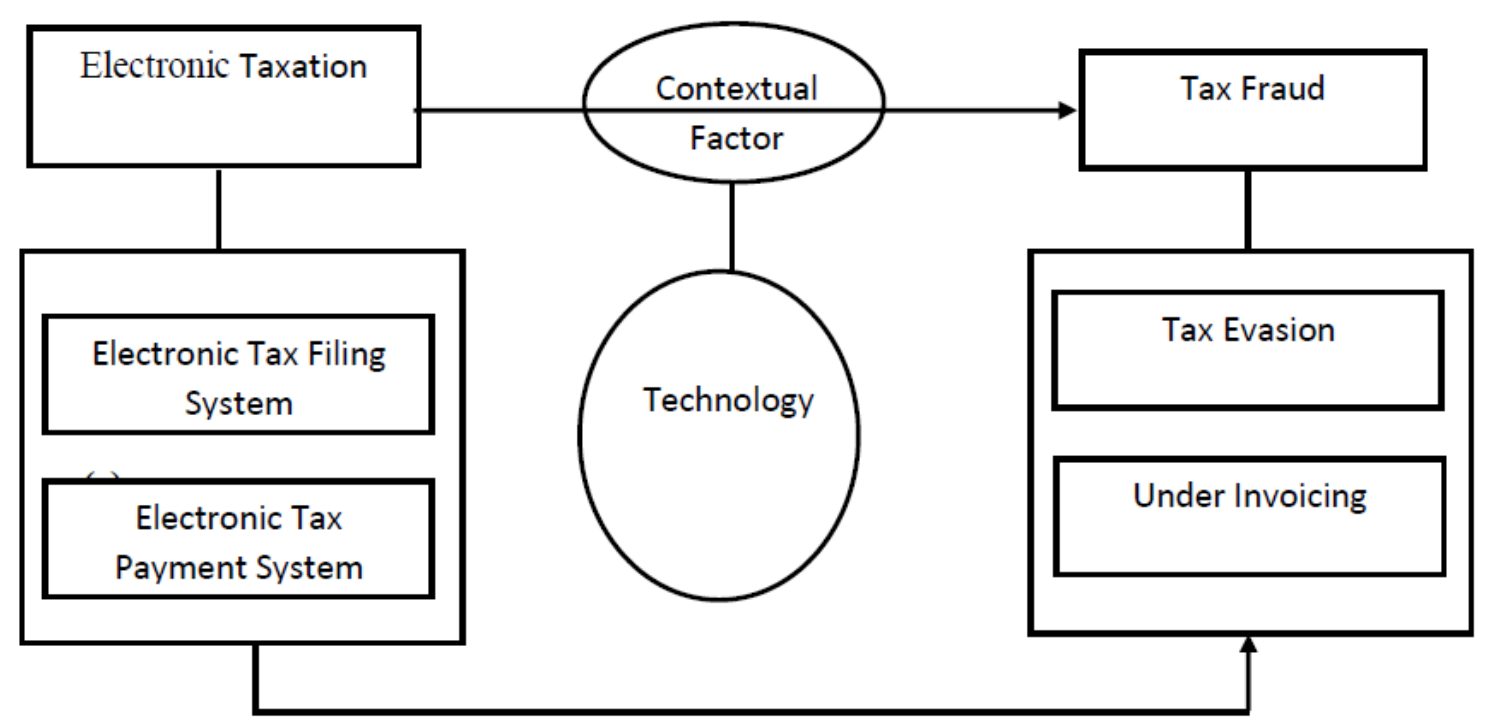

Figure1.1. Relationship between electronic taxation and tax fraud in Rivers State.

Modern tax administration seeks to focus on three key objectives: enabling voluntary compliance; providing adequate tax records for easy communication of information and professionally minimise the cost of collection. This served as the main function which led to the most established use of IT systems in tax administrations. The version of information technology in the implementation of core tax procedures such as registration, filing of returns, payments and general maintenance of database brought about what is now known as an electronic-based tax system commonly referred to as e-tax. Etax can then be defined as the automation of core tax processes that suggests electronic registration, filing, and payment, as well as education and information to taxpayers. Without mincing word, the three- tax system is a complete internet portal that forms a suite of secure self- service options to taxpayers, may provide a single point for material and action; is that is has 24 hours availability, seven days a week and does not require involvement from tax administration staff.

\subsection{Electronic Tax System in Nigeria}

The year 2013 saw the birth of tax computerisation process by the Federal Inland Revenue service with the introduction of the Integrated Tax Administration System (ITAS). The system encompasses a set of programmes that is meant to simplify and improve tax administration, encourage voluntary compliance and safeguarding linkages with other stakeholders via the use of technology. The software is specifically meant to meet the needs of developing countries who wish to increase their control over State revenue by preparing themselves with computerised systems.

According to several press releases by the FIRS has opined that, the introduction of ITAS is to change the current manual system of filing tax returns thereby abridging tax compliance, ease of access to tax services and payment processes. According to FIRS press releases (Vanguard 2013, This Day Live 2013 and Punch 2015), a full implementation of ITAS (e-taxation) will assists corporation to: explain the problems of the traditional physical system of taxation in Nigeria; (ii) to provide modernized, efficient processes that makes it easier for taxpayers and other stakeholders to cooperate with the service and in turn make the FIRS more open to taxpayer's needs, (iii) to improve voluntary tax compliance and generate a more welcoming situation for taxpayers in Nigeria, (iv) to ensure better transparency in the actions and practice of tax authorities for the sake of accountability and good stewardship,(v) to re-engineer tax administration service delivery, eliminate gaps and notices in the current administrative systems and increasing contribution to national development (vi) to minimize the general cost of administration in the core of higher tax returns. (vii) to provide reliable quality service to all taxpayers across all FIRS offices across in the nation (viii) to provide a comprehensive 
source of taxpayers information that makes it easier for FIRS to support and monitor the taxpayer base through the lifecycle of each taxpayer and (ix) to reduce tax evasion. ITAS include income tax, VAT, sales tax and other indirect taxes, licenses and permits (alcohol, professional etc.), pay as you earn, excise duty, driving licenses and motor vehicle registration, general income, property taxes, concealment taxes and others.

Nothing in the world is free; for government to provide these things it also has to pay for them, but most organisation will not want to assist government to achieve it. This is not feasible mostly in developing economies. Most firms would prefer to make all the profit and would deny government their due in form of tax.

The intentional act of a tax pay payer (individual, corporate bodies, Trust etc.) not to pay tax is an act of sabotage to the government. This act is known as tax evasion. According to Edwin (2007 p:2) anybody or institution who illicitly refuse to pay their tax and recording true and fair value of their earnings by a means of escaping is practicing tax evasion. Tax evasion is characterised as a deliberate wrongful attitude, or as a behaviour relating a straight desecration of tax laws, norms and ethics regarding citizenry obligation to leakage the payment of tax. The deliberate underreporting of revenue, as well as over-claiming of a tax deduction, is an obvious example of tax evasion (Adebisiand Gbegi, 2013).Soyode and Kojola (2006) assert that an intentional and aware repetition of not revealing full taxable income is tax evasion. It is a desecration of tax laws in which the tax rate owed by a taxable person is unpaid after the minimum essential period (Temitope, Olayinkaand Abdurafiu, 2010).

Tax evasion is clear evidence in a condition where taxpayers are falling, making or asserting false statement about their obligations on the revenue tax through controlling ineffectiveness in the tax laws and regulations. Tax evasion usually involves taxpayers deliberately perverting or hiding the true situation of their affairs to the applicable tax authorities to ease their tax burden. However, tax evasion can be confidential as full evasion or partial evasion (Fakileand Adegbie, 2011). Partial evasion happens when an individual or corporate unit understated its earnings for tax and proclaim low income while full evasion occurs when the person or corporate organisation qualified to pay tax but fail to register with tax authorities to join in the tax system. This act includes, in detailed, false tax recording like declaring fewer earnings and overloading deductions. Legally, tax evasion is a crime and subject to performance by way of fine, imprisonment or even both in many countries of the world.

Richardson (2008) asserts that tax evasion as an intentional, illegal and intolerable behaviour or activities involving a direct violation of tax law to evade the expenditure of tax. Kim (2008) believes that tax evasion is illegal and desecration of tax laws, whereas tax avoidance is a legal way of diminishing tax burden. Both the two are not acceptable but the latter is less serious to the former in eroding the revenue generation use for supporting public expenditure. Olatunde (2007) and; Sikka and Hampton (2005) without mixing words concluded that tax evasion is among the main social evils hindering progress in developing nations and eroding the prevailing welfare of the public in developed markets in the world. Tax evasion occurs mostly in an informal economy where activities of businesses and other trade dealings take place in an informal manner which eases the evasion. It is very prominent when a business is not registered with tax authorities and in most cases are operating in remote areas moving from one location to another freely.As a result of this situation, economic growth will become stationary and be far away from reaching socio-economic impact and benefits to the public. Based on the foregoing, we propose that: $\mathbf{H O}_{1}$ There is no significant relationship between electronic tax filing system and tax evasion in Rivers State.

When a transaction takes place, there is the need to have an evidence of the transaction whether in or credit basis. The buyer and the seller will need to account for the transaction to all stakeholders including the government. Government wants every firm to progress because such progress will benefit the government through the collection of tax. An invoice is a document for sale of goods or a service rendered. The invoice normally states the names of the parties (The seller and the buyers) and the goods purchased/services rendered and adds any applicable sales tax or VAT. It may also include the terms of sale (applicable if it is a credit transaction).

The act or practice of stating the price of goods on an invoice below the actual price paid. Under invoicing occurs if the importer and /or exporter wish to reduce the tariff of if the buyer and /or the seller wish to reduce their apparent profits so as to pay less tax. This is very common on direct 
imported car and other materials that have high cost. For imported goods, it may attract less revenue $(\operatorname{tax})$ to the government. Hence our second hypothesis- $\mathbf{H O}_{2}$ : There is no significant relationship between the electronic tax filing system and under-invoicing in Rivers State.

Integrated Tax Administration System (ITAS) is a project to automate all core processes around registration, payment, assessment, debt and credit management and yields substantial result for government and reduce stress and operating time for both parties. Though a few of the taxpayers in Nigeria are now using the system, the FIRS is still working to full implementation of the platform throughout the country.PWC (2009), outlined the followings as the basic features of the e-filling system: (i) Online proposal of tax returns system which consists of an online portal over which taxpayers submit returns for changed taxes such as companies income tax, capital gains tax, valueadded tax, petroleum profit tax etc. Once the taxpayer registers, an e-tax filling account will then be produced based on the type of taxes the company or individuality liable to pay. A taxpayer will nevertheless only be able to file returns based on the tax it registered for (ii) Electronic tax clearance certificate (e-TCC): Under the guide system, a tax clearance certificate (TCC) is regularly issued by the board to the taxpayer (Kiable and Nwokah 2009) whenever the board feels that that tax measured on profits or income of a taxable person has been fully paid or no tax is due on such profit. One of the benefits of ITAS to taxpayers is that the application for Tax Clearance Certificates (TCC) can now be made online, processed and the hard copy picked up within 24 hours. The system allows for TCC corroboration so that a TCC can be verified by third events online using the TCC number when doing business. It also offers temporal TCC where there is an uncertain dispute concerning taxes so that the taxpayer does not suffer excessively for the delay. A full TCC can be obtained after the dispute is settled.

(iii) Substantiation of Tax Identification Number (TIN): This feature is specifically useful in verifying the tax identification number for withholding tax purposes amongst a group of other taxes. The process ensures accountability as well as validation of tax transaction with the taxpayer. (iv) Online correspondence with FIRS: The portal has a message centre feature that allows for communication among the taxpayer and FIRS. The tax account manager in the FIRS will be accountable for correspondence with the taxpayer and the FIRS can also issue valuations which taxpayers can object to using the message centre. (v) Electronic tax payment: Following the adoption of e- system of taxation, returns or payments are made online from the taxpayer's corporate bank account. This application which was developed in combination with the Nigeria Inter-Bank clearing system (NIBBS) is introduced on the respective commercial bank's internet -banking platform. Having xrayed the literature, we propose our third hypothesis which states thus: $\mathbf{H O}_{3}$ There is no significant relationship between the electronic tax payment system and tax evasion in Rivers State.

Electronic tax is supposed to be a solution to most of our tax administration problems in Nigeria, like every other system there are challenges attributable to its adoption and operation. Some of which include: (i). Trust, security and privacy concerns prevail: Taxpayers are concerned with the use of the data they provide during transactions. There are cases where illegal access to taxpayer information as a breach in security and therefore many taxpayers are startled about such information is getting into the wrong hands which might lead to fraud. The activities of hackers who disturb websites also affect the system. (ii). High level of illiteracy: Nigeria, unfortunately, has a low population of literate people and an even lower percentage of people who are computer literate. As a result of this, most taxpayers who are not technically uncovered shy away from the system and stick to the more primitive methods they are already used to. The brave ones who are willing to try often fall prey to fraudsters and hackers. The knowledge of e-tax in businesses has become a challenge worldwide. (iii) General struggle to change: This one of the key issues with applying the system. Most people have their mindset on not responding to a new system even before they know what it is about simply because they are already relaxed with the normal way things are done and would not want to leave their comfort zone. It is on this premise that we state our fourth hypothesis which states thus: $\mathbf{H O}_{4}$ There is no significant relationship between electronic tax payment system and under-invoicing in Rivers State.

Developed economies are striving to return to higher levels of competitiveness while fighting the stubbornly high levels of unemployment, especially among youth; at the same time, developing and emerging economies are focusing on innovation as a prerequisite to sustain the high economic growth rates they have experienced in more than three decades and leapfrog toward higher levels of economic 
and social prosperity (Brende and Greenhill 2013). It therefore implies that the role that information technology (IT) can play to support economic growth and the creation of high quality jobs has never drawn so much attention and research. There had been some initial concerns about the risk, in some developed economies, that Information and Communication Technology could accelerate the delocalisation of certain economic activities toward developing countries. However, the benefits of ICTs are now widely recognised everywhere as an important source of efficiency gains for companies that will allow them to optimize their production function and liberalize resources toward other productive investments. Moreover, ICTs are also increasingly recognized as a key source of innovation that can generate increased economic growth and new sources of high-value-added jobs. This ability to innovate is essential in the current information revolution that is transforming economic and social transactions in our societies.

The introduction of electronic tax system is in line with the adoption of IT and it is achievable if properly implemented. The process can be done in many ways including; Through the ATM/Debit/Credit card. In this situation, the taxpayer simply logs into the website of the appropriate tax authority with his TIN and then concludes the form choosing ATM/Credit card as a means of payment constructed on the selected tax levy. After entering the pin and authorizing payment, a printable e-receipt is then made available to the taxpayer. (i) Directly through bank accounts; Here the taxpayer pays in the relevant collecting bank by cash or cheque and then enters the transaction password or teller number online logging on with his TIN. After confirmation, a printable e-receipt is made available to him. $\square \square \square \square$ National electronic fund transfer; Here the taxpayer instructs his bank to make payments into the relevant collecting bank which when done provides the taxpayer with the relevant transaction codes for the payment. He then enters the code online and is furnished with an ereceipt as prove of payment. (iii) Taxpayers who have not transferred to the ITAS system can still contribute to electronic payment of taxes which is a more direct and corruption-free method for paying taxes. (iv) Automatic obligation of late filing penalties and interests: The system has been programmed to automatically compute and impose interest and penalty for late submissions of tax returns or late payment of taxes (v) Automatic allocation of withholding tax credit (WHT) to taxpayers: although this feature is not yet functional, it is calculated to automatically credit taxpayers for WHT deductions they have writhed which have already been remitted to FIRS by their customer(s). (vi) Offers the possibility of developing edges to share the data with external systems such as customs, government financial software or other government divisions. (vii) Document management, objection case management, objections (appeals) and payment agreements handling. If all these are possible in developed economies, we therefore in our fifth hypothesis proposed that: $\mathbf{H O}_{5:}$ Technology does not significantly moderate the relationship between electronic taxation and tax fraud in Rivers State.

\section{Methodology}

According to Kothari (2004) research methodology is a way to systematically solve the research problem. It can be seen as a science of studying how research is done scientifically. In it we study the various steps that are generally adopted by a researcher in studying his research problem along with the logic behind them.

The simple probability technique was used in this study because it has an equal chance of inclusion in the sample. The results obtained from probability (also known as random) sampling can measure the errors of estimation or the significance of results obtained from a random sample, and this fact brings out the superiority of random sampling design over the deliberate sampling design.

The population of this study is made up of five hundred and seventy-six (576) staff of the fifteen branches of the Rivers State Internal Service in Rivers State and listed in table 1.1 in appendix (1).The sample size was determined from the accessible population using the Taro-Yamen's formula thus:

$$
\mathrm{n}=\frac{\mathrm{N}}{1+\mathrm{N}(\mathrm{e})^{2}}
$$

Where: $\quad \mathrm{n} \quad=\quad$ sample size

e $\quad=\quad$ level of significance

$\mathrm{N} \quad=\quad$ population 
Hence;

$\mathrm{n}$

$$
=\frac{\mathrm{N}}{1+\mathrm{N}(\mathrm{e})^{2}}
$$

$\mathrm{N} \quad=576$

e $\quad=\quad$ level of significant of 0.05

$\mathrm{n}$

$$
=\frac{\frac{576}{1+576(0.05)^{2}}}{\frac{576}{1+1.44}}=236
$$

Therefore the sample size of this study is 236 staff made up from head office and the 14 branches of the Rivers State Internal Service (RIRS). The data was collected via the use of structured questionnaire which was distributed and retrieved by us. The research instrument were validated using Cronbach alpha coefficients of .966 with a reliability of .967 as detailed below as 3.1. Descriptive statistics which covers; the mean scores, standard deviation, sum etc. was used to portray the univariate characteristics of each variable.

Table3. Population of the Study (Samples from Rivers State Revenue Board Service)

\begin{tabular}{|l|l|l|}
\hline S/N & Office & Respondents \\
\hline 1. & IRS Head Office & 87 \\
\hline 2. & Port Harcourt Tax Office & 48 \\
\hline 3. & Borikiri Tax Office & 37 \\
\hline 4. & Obio/Akpor Tax Office & 45 \\
\hline 5. & Ada George Tax Office & 49 \\
\hline 6. & Diobu Tax Office & 41 \\
\hline 7. & Aba Road Tax Office & 33 \\
\hline 8. & Eleme Tax Office & 43 \\
\hline 9. & Bori Tax Office & 23 \\
\hline 10. & Tai Tax Office & 35 \\
\hline 11 & Oyigbo Tax Office & 38 \\
\hline 12 & Omoku Tax Office & 26 \\
\hline 13 & Isiokpo Tax Office & 25 \\
\hline 14 & Ahoada Tax Office & 21 \\
\hline 15 & Bonny Tax Office & 25 \\
\hline & Total & 576 \\
\hline
\end{tabular}

\subsection{Reliability Statistics}

Reliability of an instrument is the degree to which a measuring instrument gives the same scores over repeated trials. Survey instrument was used to measure the variables using Cronbach alpha, Pearson product correlation coefficients, descriptive statistics to portray the univariate characteristics of the variables, mean scores, standard deviation etc.

Figure3. Reliability statistics

\begin{tabular}{|l|l|c|}
\hline Cronbach Alpha & Cronbach Alpha Based on Standardized items & No. of items \\
\hline .966 & .967 & 5 \\
\hline
\end{tabular}

The reliability statistics for the research instrument (i.e. the questionnaire) used in this study the value of the Reliability obtained was over 0.967 which implies that the questions included in the questionnaire were statistically reliable.

\section{ANALYSis OF DATA}

Of the two hundred and thirty-six (236) copies of the questionnaire distributed, only two hundred and nineteen were returned, one hundred and ninety-four (194) (82.2\%) was valid, twenty-five (25) or $(10.6 \%)$ was invalid as a result of improper filling while seventeen (17) or 7.2\% were not returned. 


\subsection{Univariate Analysis}

Table4.1. Descriptive Statistics

\begin{tabular}{|l|l|l|l|}
\hline & $\mathrm{N}$ & Mean & Std. Deviation \\
\hline e-tax filing system & 194 & 3.87 & 1.057 \\
\hline e-tax payment system & 194 & 3.94 & 0.993 \\
\hline under-invoicing & 194 & 2.70 & 0.866 \\
\hline tax evasion & 194 & 3.71 & 1.192 \\
\hline Technology & 194 & 4.13 & 0.853 \\
\hline Valid N (listwise) & 194 & & \\
\hline
\end{tabular}

The univariate analysis result shows that e-tax filing system, e-tax payment system, under-invoicing, tax evasion and technology had mean values of 3.87, 3.94, 2.70, 3.71 and 4.13 respectively with a standard deviation of 1.057, 0.993, 0.866, 1.192 and 0.853 (see appendix 11).

The bivariate analysis involves the relationship between two variables. The relationship between the variables will be analysed using Pearson Product Correlation Coefficient. Also, the hypotheses so far raised in the study are analysed using the significance of the Pearson Product Correlation Coefficient at $1 \%$ level of significance (see Table 4.2).

\subsection{Relationship Between Electronic Tax Filing System and Tax Evasion}

The coefficient shows (see appendix 11) that there exists a negative relationship between the electronic tax filing system and tax evasion with a coefficient of -0.836 . This implies that an increase in electronic tax filing system will reduce tax evasion by approximately $84 \%$. The significance of this relationship is 0.000 which is less than the $1 \%$ level of significance. We therefore reject the null hypothesis and conclude that there is a significant relationship between the electronic tax filing system and tax evasion in Rivers State.

\subsection{Relationship Between Electronic Tax Filing System and Tax Under-Invoicing}

Appendix 11 shows that in the coefficient there exists a positive relationship between the electronic tax filing system and tax under-invoicing with a coefficient of 0.665 . This implies that an increase in electronic tax filing system will increase tax under-invoicing by approximately $67 \%$. The significance of this relationship is 0.000 which is less than the $1 \%$ level of significance. We therefore reject the null hypothesis and conclude that there is a significant relationship between the electronic tax filing system and tax under-invoicing in Rivers State.

\subsection{Relationship Between Electronic Tax Payment System and Tax Evasion}

There exists a negative relationship between the electronic tax payment system and tax evasion with a coefficient of -0.780 (see appendix 11). This implies that an increase in electronic tax payment system will reduce tax evasion by approximately $78 \%$. The significance of this relationship is 0.000 which is less than the $1 \%$ level of significance. By this result, the null hypothesis is rejected and thus accept the alternate hypothesis which states that: there is a significant relationship between the electronic tax payment system and tax evasion in Rivers State.

Table4.2. Correlations matrix

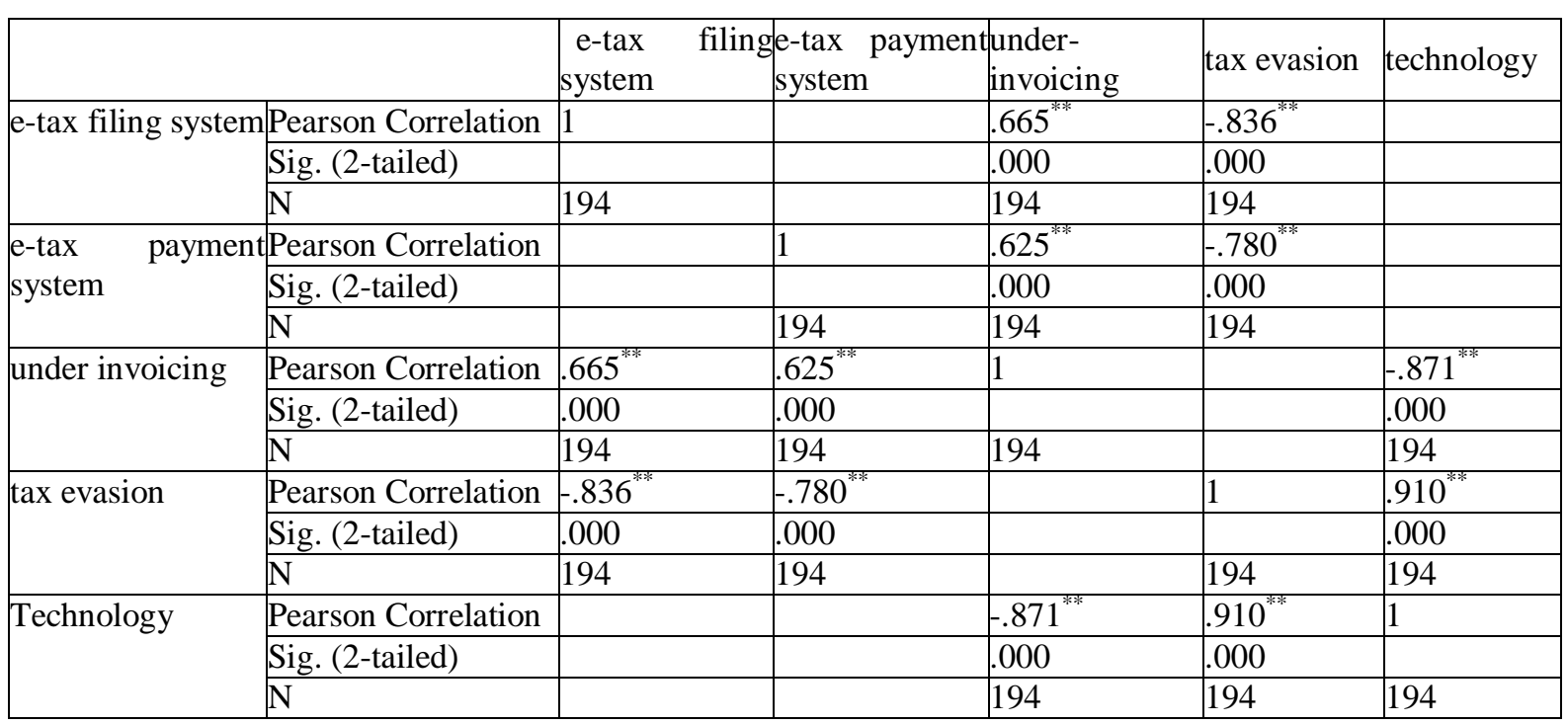




\subsection{Relationship Between the Electronic Tax Payment System and Tax Under-Invoicing}

The coefficient as exhibited on table 4.2shows that, there exists a negative relationship between the electronic tax payment system and tax under-invoicing with a coefficient of 0.625 . This implies that an increase in electronic tax payment system will increase tax under-invoicing by approximately $63 \%$. The significance of this relationship is 0.000 which is less than the $1 \%$ level of significance. The null hypothesis is rejected and the alternate accepted (there is a significant relationship between the electronic tax payment system and tax under-invoicing in Rivers State).

\subsection{Relationship Between Technology, Electronic Taxation and Tax Fraud}

The above table shows that there exists a positive relationship between technology and tax evasion (0.910) while there is a negative relationship between technology and tax under-invoicing at (0.871). This implies that technology encourages tax evasion while it helps reduce the incidence of tax underinvoicing. The significance of this relationship is 0.000 which is less than the $1 \%$ level of significance. We therefore reject the null hypothesis and conclude that technology significantly moderates the relationship between electronic taxation and tax fraud in Rivers State.

\subsection{Discussion and Policy Implications of Findings}

The study adopted bivariate analysis using the Pearson Correlation Coefficient to evaluate the relationships among the variables in the study. From the analysis, it was observed that the electronic tax filing system has an inverse relationship with tax evasion. It was further observed that electronic tax payment system has an inverse relationship with tax evasion. Under- invoicing form, revealed a positive relationship with electronic tax filing system as well as electronic tax payment system. Technology also was observed to have encouraged tax evasion while reducing tax under-invoicing. This implies that with the proper electronic tax filing system, tax evasion will reduce in Rivers State. It was also observed that electronic tax payment system has an inverse relationship with tax evasion. In summary, electronic taxation has helped in reducing the incidence of tax fraud in Rivers State. Therefore with adequate and efficient tax filing and payment system, there will be a reduction in tax fraud in Rivers State.

\section{CONCLUSION AND RECOMMENDATIONS}

This study evaluated the impact of electronic taxation on tax fraud using River State as a case study. It highlighted the relationship between the electronic tax filing system, electronic tax payment system, tax evasion and tax under-invoicing. It also showed the role of technology in improving electronic taxation as well as its role in curbing tax fraud in the State. It was observed that electronic tax filing system has an inverse relationship with tax evasion. This implies that with proper supervision of electronic tax filing system, tax evasion will reduce in Rivers State. It was also observed that electronic tax payment system has an inverse relationship with tax evasion. Therefore electronic taxation has significantly and adequately reduced tax evasion in the State. From the study we observed that under- invoicing has a significant relationship with electronic tax filing system as well as electronic tax payment system. This implies that electronic taxation have not been able to curb tax under-invoicing in River State. It was further observed that technology cannot adequately curb tax fraud, other factors have to also be in place to significantly reduce tax fraud in Rivers State.

Based on the findings we recommend that: (1) Efforts should be made by various institutions in Nigeria saddled with the responsibility of tax administration to embrace electronic taxation as this will have a huge role to play in reducing the incidences of tax evasion and tax under-invoicing in (2) Tax personnel should be sufficiently trained regularly to keep up-to-date with the latest developments in the tax system. (3) Efforts should also be made to ensure that corporate bodies in Rivers State have active bank accounts where their taxes could be deducted at source. (4) There is also a need for adequate tax equipment and facilities to sustain the rapidly evolving electronic tax system. This will not only reduce incidences of tax evasion and tax under-invoicing but also make the tax payment system easy, transparent and ensure simplicity of tax payment system. Finally (5) tax authorities at all levels of government (federal, state and local) should engage in massive awareness campaigns to enlighten taxpayers on tax payment with much emphasis on easier ways of tax payment brought about by tax reforms. 


\section{REFERENCES}

[1] Adebisi J. F. \&Gbegi, D.O (2013) Effect of tax avoidance and tax evasion on personal income tax administration in Nigeria. American Journal of Humanities and Social Sciences, 1( 3): 125-134.

[2] Armstrong, C. Blouin, J.\&Larcker, D. (2012). The incentives for tax planning, Journal of Accounting and Economics, Vol. 53: 391-411.

[3] Brende, B. and Greenhill, R. (2013). The Global Information Technology Report 2013 Growth and Jobs in a Hyper-connected World. Insead and World Economic Forum

[4] Dyreng, S. Hanlon, M. \& Maydew, E. (2010). The effects of executives on corporate tax avoidance. The Accounting Review, Vol. 85: 1163-1189.

[5] Dyreng, S. Hanlon, M; Maydew, E;\&Thornock, J. (2017). Changesin corporate effective tax rates over the past 25 years. Journal of Financial Economics, Vol. $\quad$ 124: 441-463.

[6] Fakile A.S. \&Adegbie, F. F. (2011).Company income tax and Nigeria economic development. European Journal of Social Sciences, 2 (6): 326-330

[7] Huber, N. (2017). Indirect taxes but a direct business impact. EY-Tax Insights for business leaders No.13.

[8] Kiabel, B.D. \&Nwikpasi, N.N. (2009).Selected aspects of Nigerian taxes (Revised Edition. Port Harcourt: Mgbaa Commercial Enterprise.

[9] Kiabel, D.B. \& Nwokah, G. N (2009). Boosting revenue generation by state government in Nigeria: The tax consultant option revisited. European journal of science, 15: 60-67.

[10] Kothari, R. C. (2004). Research Methodology: methods and techniques. New Delhi, New Age International (P) Ltd., Publishers.

[11] Lex, C. H. (2016).Can Electronic Tax Invoicing Improve Tax Compliance? A Case Study of the Republic of Korea's Electronic TaxInvoicing for Value-Added Tax. Equitable Growth, Finance and Institutions Global Practice Group, World Bank Group, March.

[12] Madumere, I. (2019). The nexus between good governance and voluntary tax payment: evidence from SMEs in Rivers State, Nigeria. Journal of Accounting Research. Adamawa State University, Mubi. Vol. 7, No. $1 \& 2: 177-188$.

[13] Morozumi, A. and Veiga, F.J. (2016). Public spending and growth: The role of government accountability European Economic Review 89:148-171.

[14] Nwaobia, A., Kwarbai, J., \&Ogundajo, G. (2016). Tax Planning and Firm Value: Empirical Evidence from Nigerian Consumer Goods Industrial Sector (Vol. 7).

[15] Osario, B. B.; Dutta, S. and Lavin, B. (2013). The Global Information Technology Report 2013 Growth and Jobs in a Hyper-connected World. Insead and World Economic Forum.

[16] Olatunde, J.O. (2007). Tax evasion, tax avoidance and corruption: An interface with source of finance for development in Nigeria. Lagos Glorious press.

[17] Price Waterhouse Coopers (PwC) (2009), Small Medium Enterprises Total Tax Contribution Report Report Commissioned by the Australian Department of the Treasury. Retrieved April 06, 2020 from http://taxr eview. treasury.gov.au/content/html/commissioned_work/downloads/pricewaterhousecoopers.

[18] Richardson, G. (2008).The Relationship between Culture and Tax Evasion Across Countries: Additional Evidence and Extensions. Journal of International Accounting, Auditing and Taxation, 17: 67- 78.

[19] Sikka, P. and M.P. Hampton, (2005). The role of accountancy firms in tax avoidance: Some evidence and issues. Accounting Forum, 29(3), 325-343

[20] Soyode, L. and S.O. Kajola, (2006).Taxation: Principles and practice in Nigeria, $1^{\text {st }}$ Edition. Silicon, Ibadan

[21] Temitope, O.F., Olayinka, M.U \&Abdurafiu, O.N (2010). The ethics of tax evasion: Perceptual evidence from Nigeria. European Journal of Social Science, 8(3): 360- 371.

[22] Thomas, R. (2017).Emerging markets plot a new tax road map. EY Tax insight for business leaders.

[23] Xing, J. (2012). Tax structure and growth: How robust is the empirical evidence? Economics Letters, 117 (1):379-382.

\section{AUTHORS' BIOGRAPHY}

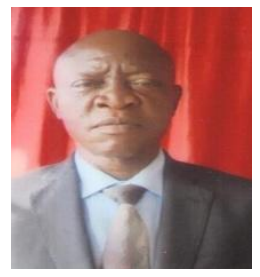

Dr. Ifeanyi Madumere, Lecturer Department of Accounting, Federal University Otuoke, Bayelsa State Nigeria. 


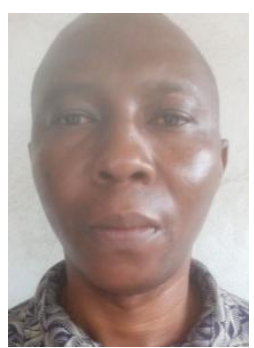

George Iheanacho Ubani, PhD. Candidate, Ignatius Ajuru, University of Education, Port Harcourt Nigeria

Citation: Ifeanyi Madumere PhD, George IheanachoUbani, "Electronic Taxation and Tax Fraud in Rivers State" International Journal of Managerial Studies and Research (IJMSR), vol 8, no. 6, 2020, pp. 1-12. doi: http:// dx.doi.org/10.20431/2349-0349.0806001.

Copyright: (1) 2020 Authors. This is an open-access article distributed under the terms of the Creative Commons Attribution License, which permits unrestricted use, distribution, and reproduction in any medium, provided the original author and source are credited. 